\title{
KEGIATAN PENGELOLAAN SAMPAH DAN PENGHIJAUAN OLEH DASA WISMA AZALEA RT 3 RW 16 DESA MANGLIAWANKECAMATAN PAKIS KABUPATEN MALANG
}

\author{
Susilo Bekti ${ }^{1}$, Ardian Anjar Pangestuti², Enis Fitriani ${ }^{3}$ \\ 1), 2), 3) IKIP Budi Utomo \\ ${ }^{1}$ Email: susilobekti2006@gmail.com \\ ${ }^{2}$ Email: ardianpangestuti@gmail.com \\ ${ }^{3}$ Email: fitrianienis@gmail.com
}

\begin{abstract}
The Environmental Office OF Malang Regency (DLH) noted that the amount of waste produced by the people of Malang Regency reached 1004.58 tons/day and as many as 273.33 tons/day waste could not be utilized. Dasa Wisma Azalea is one of the environmental activist community in RT 03 RW 16 Mangliawan Village, Pakis Subistrict, Malang Regency. The thought from the members of Dasa Wisma Azalea stated that the members of community took part in increasing the amount of waste generation in Malang Regency. Based on this thought Dasa Wisma Azalea carried out efforts to manage waste generated by the members of community and plant a variety of useful plants. The programs carried out by Dasa Wisma Azalea include conducting comparative study activity, procuring inorganic storage areas, procuring composter barrels, sorting organic and inorganic waste, making organic fertilizer, sorting inorganic waste, utilizing inorganic waste, buying family medicinal plants (TOGA), vegetables, fruitproducing plants and ornamental plants, as well as maintaining and harvesting the plants. These activity program worked well, this was proven by the RT 03 environment got the 3rd rank in the environmental competition in August 2018 whereas in the previous year RT 03 got the 7 th rank.
\end{abstract}

Keywords: Waste Management, planting TOGA, Dasa Wisma Azalea

\section{ANALISIS SITUASI}

Pengelolaan sampah selalu menjadi masalah serius bagi pemerhati lingkungan. Hal ini karena hingga saat ini timbulan sampah yang dihasilkan oleh masyarakat belum seluruhnya dapat terkelola dengan baik. Salah satu informasi yang perlu kita ketahui bersama adalah pemukiman atau rumah tangga merupakan penyumbang sampah terbesar (Darmawan, 2019 \& Ramon, 2015). Salah satu penyebab terjadinya kondisi ini karena masyarakat masih menganut paradigma lama tentang pengelolaan sampah, dimana sampah itu dikumpulkan-diangkut dan dibuang (Sudiro, 2018). Masalah pengelolaan sampah rumah tangga tidak boleh dibiarkan terjadi berlarut-larut, karena semakin lama jumlah sampah akan semakin meningkat. Sebagaimana kita ketahui bersama bahwa jumlah penduduk Indonesia mengalami peningkatan dari waktu ke waktu. Peningkatan jumlah penduduk menyebabkan peningkatan aktivitas penduduk, dan peningkatan aktivitas penduduk menyebabkan peningkatan jumlah timbulan sampah (Ramon, 2015; Darmawan, 2019; \&Sudiro, 2018).

Bagaimanakah dengan jumlah timbulan sampah di Kabupaten Malang? Dinas Lingkungan Hidup (DLH) Kabupaten Malang mencatat, bahwa jumlah sampah yang dihasilkan oleh masyarakat Kabupaten Malang mencapai 1004,58 ton/hari (Erwin, 2019). Lebih lanjut disampaikan bahwa sebanyak 566,37 ton/hari sampah sudah diproses menjadi kompos; sebanyak 69,16 ton/hari sampah sudah didaur ulang; sebanyak 1,21 ton/hari sampah digunakan sebagai

Susilo Bekți - Kegiatan Pengelolaan Sampah dan Penghijauan oleh Dasa Wisma Azalea RT 3 RW 16 Desa Mangliawan Kecamatan Pakis Kabupaten Malang 
bahan bakar; sebanyak 79,18 ton/hari dikelola Bank Sampah; 253,23 ton/hari diolah menjadi biogas; ditimbun di TPA sebanyak 253,23 ton/hari; dan yang belum terkelola sebanyak 20,10 ton/hari (Erwin, 2019). Berdasarkan data tersebut dapat diketahui bahwa sebanyak 273,33 ton/hari sampah belum dapat dimanfaatkan.

RT 3 RW 16 Desa Mangliawan Kecamatan Pakis, merupakan salah satu wilayah yang berada di Kabupaten Malang. Hal ini berarti, warga yang tinggal di lingkungan ini turut andil dalam menambah jumlah timbulan sampah di Kabupaten Malang. Lantas, bagaimana kondisi lingkungan di RT 3? Jika kita berkunjung ke RT 3, kita dapat menjumpai tumpukan sampah di tepi jalan maupun di lahan kosong yang ada di sekitar rumah warga. Sampah yang ada di tempat tersebut merupakan sampah rumah tangga. Sampah rumah tangga merupakan sampah yang berasal dari kegiatan rumah tangga sehari-hari yang sebagian besar terdiri dari sampah organik, tidak termasuk tinja dan sampah spesifik (sampah yang karena sifat, konsentrasi dan atau volumenya memerlukan pengelolaan khusus) (Peraturan Menteri dalam Negeri Nomor 33 Tahun 2010\& Perda Kabupaten Malang Nomor 12 tahun 2012).Sampah rumah tangga umumnya sangat beragam, tetapi secara umum minimal 75\% merupakan sampah organik dan 25\% merupakan sampah anorganik (Usman, 2016). Selain banyak dijumpai tumpukan sampah, kondisi lingkungan juga tampak panas dan gersang. Kondisi lingkungan di RT 3 sebagaimana ditunjukkan Gambar 1 dan 2.

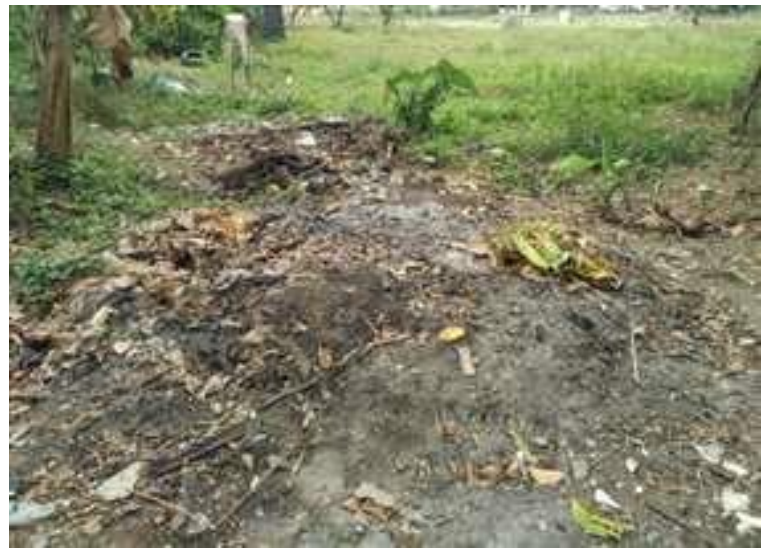

Gambar 1. Lahan Kosong yang Dijadikan Tempat Pembuangan Sampah dan Tempat Membakar Sampah

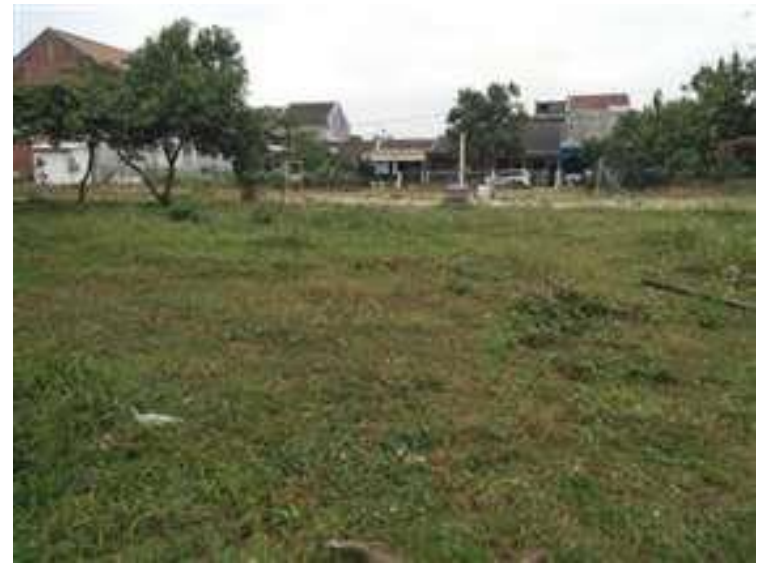

Gambar 2. Lahan Kosong yang Belum Dimanfaatkan untuk Bercocok Tanam

Masalah lingkungan yang terjadi di RT 3 disebabkan karena kesadaran dan pemahaman masyarakat untuk mengelola lingkungan masih rendah. Hal ini terbukti dari beberapa hal sebagai berikut. Pertama, kebiasaan warga membakar sampah dan membuang sampah di tepi jalan atau di lahan kosong yang ada di sekitar pemukiman. Kondisi ini diperparah dengan petugas pengambil sampah yang tidak mengambil sampah setiap hari.

Kedua, warga belum memanfaatkan pekarangan rumah atau lahan kosong yang ada di lingkungan sekitarnya untuk menanam tanaman yang bermanfaat, misalnya TOGA, sayuran, tanaman hias, maupun tanaman yang 
menghasilkan buah. Ketiga, sikap warga yanghanya antusias untuk mengelola lingkungan ketika akan diadakan kegiatan lomba. Sebagai informasi, setiap tahun (biasannya dilaksanakan mendekati peringatan hari ulang tahun RI) di lingkungan RW 16 diadakan lomba lingkungan.Peserta lomba adalah seluruh RT yang terdapat di wilayah RW 16. Seluruh RT di RW 16 berlomba-lomba untuk mendapatkan juara, hal inilah yang membuat warga antusias untuk mengelola lingkungan.

Masalah lingkungan yang terjadi di RT 3 tidak boleh dibiarkan terjadi begitu saja, karena dapat menimbulkan beberapa masalah sebagai berikut. Pertama, timbulan sampah yang ada di sekitar pemukiman warga semakin lama akan semakin banyak. Kedua, kondisi lingkungan yang kotor dapat menjadi penyebab munculnya penyakit, bau tidak sedap, dan tentunya tidak sedap dipandang mata. Ketiga, pembakaran sampah yang dilakukan warga dapat menyebabkan polusi udara. Keempat, timbulan sampah di lingkungan sekitar pemukiman dan lingkungan yang gersang dapat menyebabkan terjadinya banjir.

Berdasarkan hal yang telah disampaikan sebelumnya dan berawal dari pemikiran bahwa warga yang tinggal di lingkungan RT 3 RW 16 Desa Mangliawan Kecamatan Pakis turut andil dalam menambah jumlah timbulan sampah di Kabupaten Malang, maka Dasa Wisma Azalea VIA melakukan upaya untuk mengelola sampah yang dihasilkan oleh warganya dan menanam TOGA, berbagai sayuran, tanaman hias, serta tanaman yang menghasilkan buah. Melalui kegiatan ini, diharapkan dapat mengurangi jumlah timbulan sampah di Kabupaten Malang, terutama mengurangi jumlah timbulan sampah yang belum dapat dimanfaatkan dengan baik. Selain itu, juga sebagai upaya untuk mewujudkan lingkungan RT 3 yang hijau dan asri.

\section{METODE PELAKSANAAN}

Langkah-langkah yang dilakukan oleh Dasa Wisma Azalea VIA untuk mengelola sampah dan melakukan penghijauansebagai berikut.

1. Melakukan kegiatanstudi banding.

2. Mengadakan rapat untuk merancang program kegiatan yang akan dilaksanakan.

3. Pengadaan tempat penyimpanan sampah anorganik.

4. Pengadaan tong komposter.

5. Pemilahan sampah organik dan anorganik.

6. Pembuatan pupuk organik cair.

7. Pemilahan sampah anorganik.

8. Pemanfaatan sampah anorganik.

9. Penanaman TOGA, sayuran, tanaman yang menghasilkan buah, dan tanaman hias.

10. Perawatan dan pemanenan tanaman.

\section{HASIL DAN PEMBAHASAN}

Kegiatan yang dilakukan oleh Dasa Wisma Azalea VIA dapat dikatakan berhasil mewujudkan lingkungan RT 03 RW 16 Desa Mangliawan Kecamatan Pakis menjadi lingkungan yang bersih dan hijau. Hal ini dibuktikan dengan diraihnya peringkat III pada lomba lingkungan bulan Agustus tahun 2018. Padahal,pada lomba lingkungan tahun sebelumnya, RT 03 mendapatkan peringkat VII.

Berikut ini kegiatan yang dilakukan oleh Dasa Wisma Azalea VIA untuk mewujudkan lingkungan RT 03 yang bersih dan hijau. Pertama, melakukan kegiatan studi banding. Tujuan kegiatan studi banding adalah Jl. S. Supriyadi, Kel. Sukun, Kec. Sukun, Malang. Lokasi ini ditetapkan sebagai tujuan kegiatan studi banding karena pernah menjadi juara lingkungan tingkat Nasional.

Susilo Bekți - Kegiatan Pengelolaan Sampah dan Penghijauan oleh Dasa Wisma Azalea RT 3 RW 16 Desa Mangliawan Kecamatan Pakis Kabupaten Malang 
Ada dua tujuan yang ingin dicapai dari dilaksanakannya kegiatan studi banding ini. Pertama, meningkatkan kesadaran warga RT 03 agar bersedia mengelola lingkungannya dengan baik. Kedua, meningkatkan pengetahuan warga RT 03 dalam mengelola sampah dan melakukan penghijauan.

Pada kegiatan studi banding, warga memperoleh beberapa informasi sebagai berikut. Pertama, pemilahan sampah organik dan anorganik. Kedua, pengelolaan dan pemanfaatan sampah anorganik sehingga dapat menghasilkan uang. Ketiga, pembuatan pupuk organik cair dari bahan sampah organik. Keempat, upaya penghijauan yang dilakukan di lingkungan tersebut. Dokumentasi kegiatan studi banding sebagaimana tersaji pada Gambar 3.
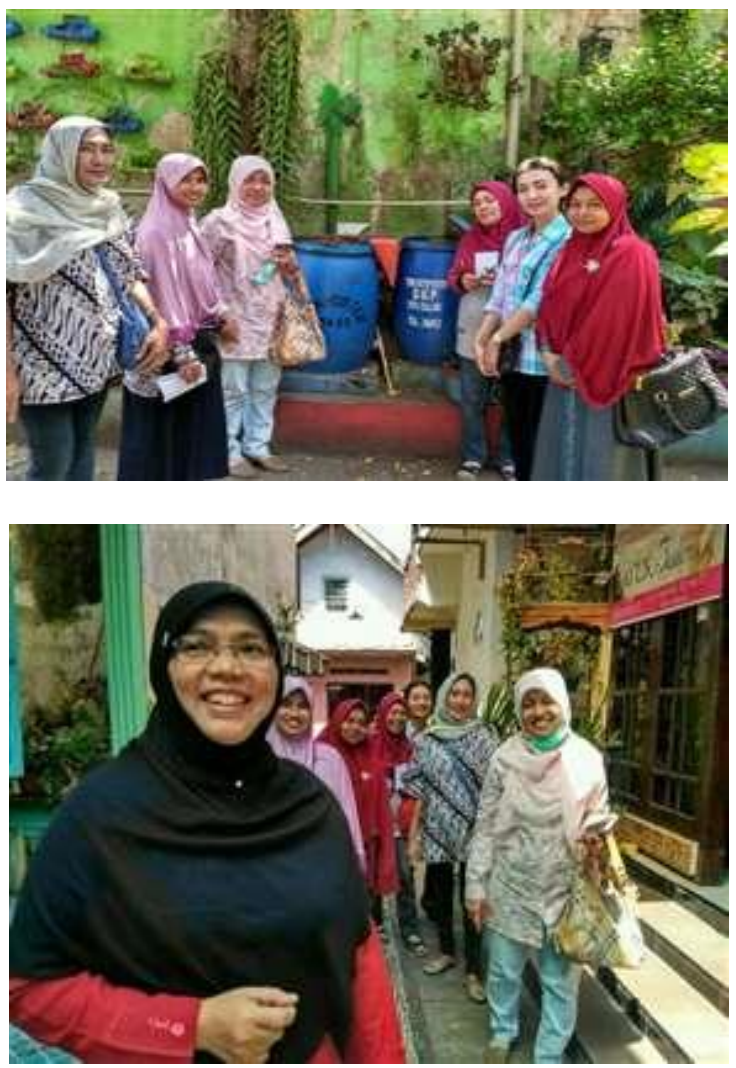

Gambar 3. Kegiatan Studi Banding di Jl. S. Supriyadi Kel, Sukun, Kec. Sukun, Malang.(Sumber: Dokumen Pribadi, 2019)
Kegiatan selanjutnya adalah mengadakan rapat untuk merancang program kegiatan untuk mewujudkan lingkungan yang bersih dan hijau. Kegiatan rapat ini diikuti oleh seluruh warga RT 03.Salah satu hasil rapat adalah warga RT 03 akan mulai mengelola sampah yang dihasilkan.

Kegiatan ketiga adalah pengadaan tempat penyimpanan sampah anorganik. Warga RT 03 sepakat untuk menggunakan rumah kosong yang ada di sekitar tempat tinggal warga sebagai tempat penyimpanan sampah anorganik (Gambar 4). Alasan dipilihnya tempat ini karena lokasinya berada di sekitar tempat tinggal warga. Dengan demikian, diharapkan warga tidak enggan datang ke tempat ini untuk meletakkan sampah anorganik yang dihasilkan dari aktivitas sehari-hari.

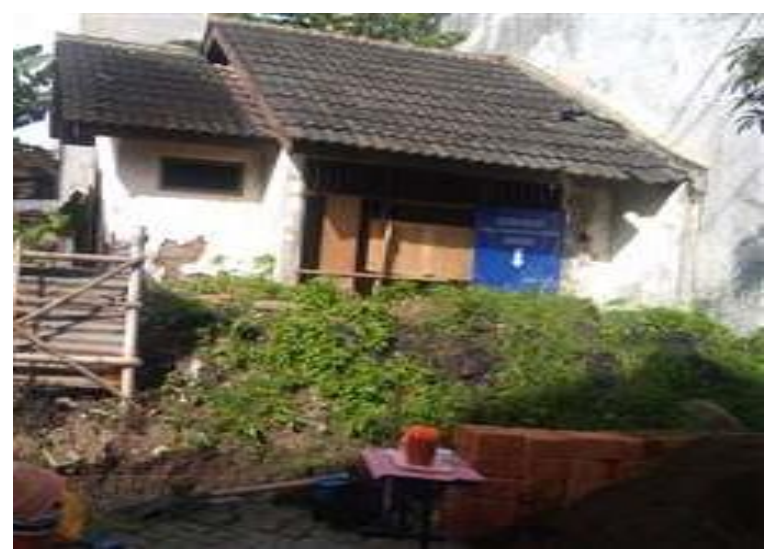

Gambar 4. Rumah kosong yang akan digunakan sebagai tempat penyimpanan sampah anorganik (Sumber: Dokumen Pribadi, 2019)

Pengadaan tempat sampah anorganik dilaksanakan melalui kegiatan kerja bakti yang melibatkan warga RT 03. Kegiatan kerja bakti terdiri atas beberapa kegiatan, antara lain: membersihkan lingkungan sekitar rumah dari tanaman liar, membersihkan bagian dalam rumah, dan memanfaatkan lahan yang ada di bagian depan rumah untuk menanam berbagai jenis tanaman. Gambar 5 merupakan dokumentasi kegiatan kerja bakti.Gambar 6

Susilo Bektti - Kegiatan Pengelolaan Sampah dan Penghijauan oleh Dasa Wisma Azalea RT 3 RW 16 Desa Mangliawan Kecamatan Pakis Kabupaten Malang 
merupakan dokumentasi rumah sampah yang siap untuk digunakan.

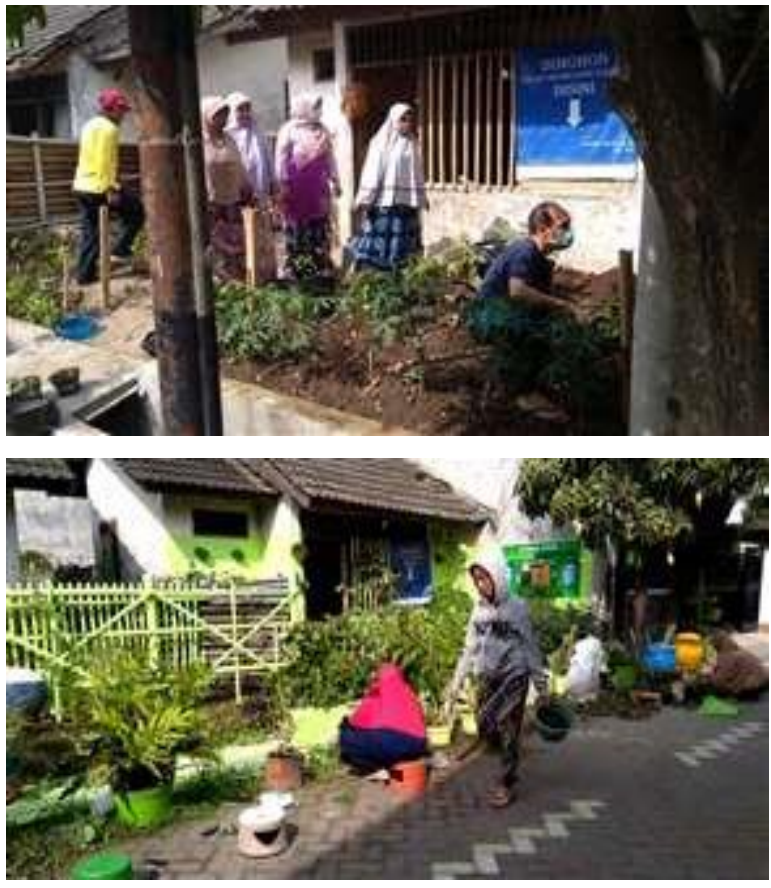

Gambar 5. Kerja bakti untuk pengadaan tempat penyimpanan sampah anorganik (Sumber: Dokumen Pribadi, 2019)

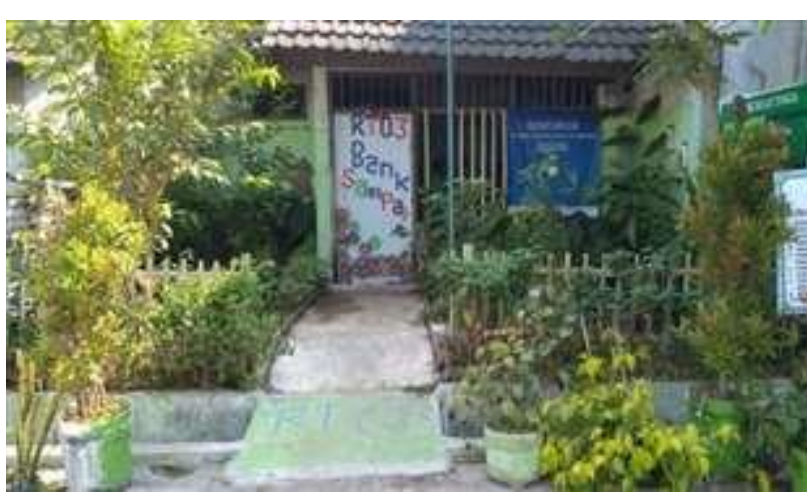

Gambar 6. Tempat penyimpanan sampah anorganik yang siap digunakan (Sumber: Dokumen Pribadi, 2019)

Kegiatan keempat adalah pengadaan tong komposter. Tong komposter diperlukan warga untuk membuat pupuk organik cair dengan bahan dasar sampah organik. Tong komposter ini selanjutnya diletakkan di tempat penyimpanan sampah anorganik. Selain lokasinya dekat dengan tinggal warga, alasan dipilihnya lokasi ini agar tong komposter berada di tempat teduh, sehingga tidak langsung terkena cahaya matahari dan air hujan. Gambar 7merupakan dokumentasi tong komposter.

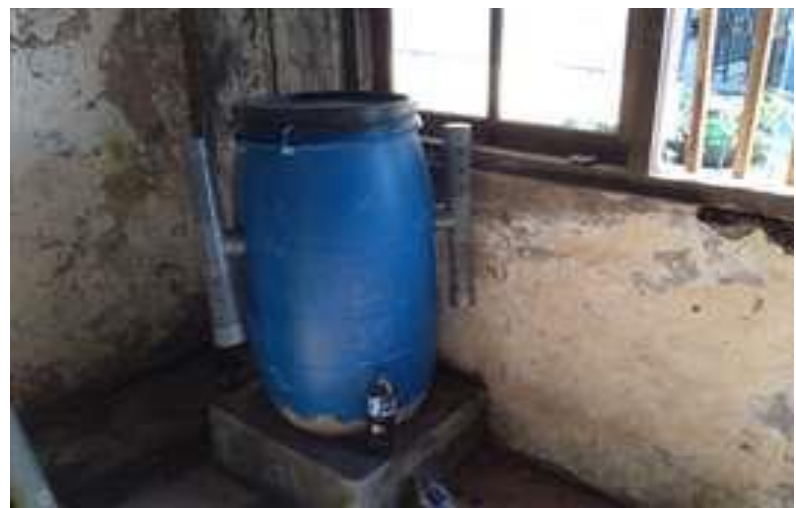

Gambar 7. Tong Komposter (Sumber: Dokumen Pribadi, 2019)

Kegiatan selanjutnya adalah pemilahan sampah organik dan anorganik.Sampah organik merupakan sampah yang berasal dari benda hidup (Perda Kabupaten Malang Nomor 12 tahun 2012). Contoh sampah organik adalah sisa makanan, kulit buah, buah atau sayur yang telah rusak, rumput, dedaunan yang gugur, dll. Sampah anorganik merupakan sampah yang berasal dari benda mati (Perda Kabupaten Malang Nomor 12 tahun 2012). Contoh sampah anorganik adalah botol plastik maupun botol kaca bekas, gelas bekas air mineral, plastik bekas bungkus minyak, dll.

Kegiatan pemilahan sampah dilakukan oleh warga di rumah masing-masing. Sampah organik (misalnya kulit buah, sisa potongan sayur yang masih mentah, atau sampah yang dihasilkan dari kegiatan berkebun) dimasukkan ke dalam tong komposter. Berbeda dengan sampah organik, sampah anorganik diletakkan pada rak-rak yang telah disediakan di tempat penyimpanan sampah anorganik.Biasanya, warga mengumpulkan sampah anorganik ke tempat penampungan sampah anorganik secara berkala, ada yang melakukannya sepekan sekali, ada pula yang dua pekan sekali, bahkan ada pula yang sebulan sekali. Gambar 8 merupakan

Susilo Bekți - Kegiatan Pengelolaan Sampah dan Penghijauan oleh Dasa Wisma Azalea RT 3 RW 16 Desa Mangliawan Kecamatan Pakis Kabupaten Malang 
dokumentasi warga yang membawa sampah anorganik ke tempat penampungan sampah anorganik.
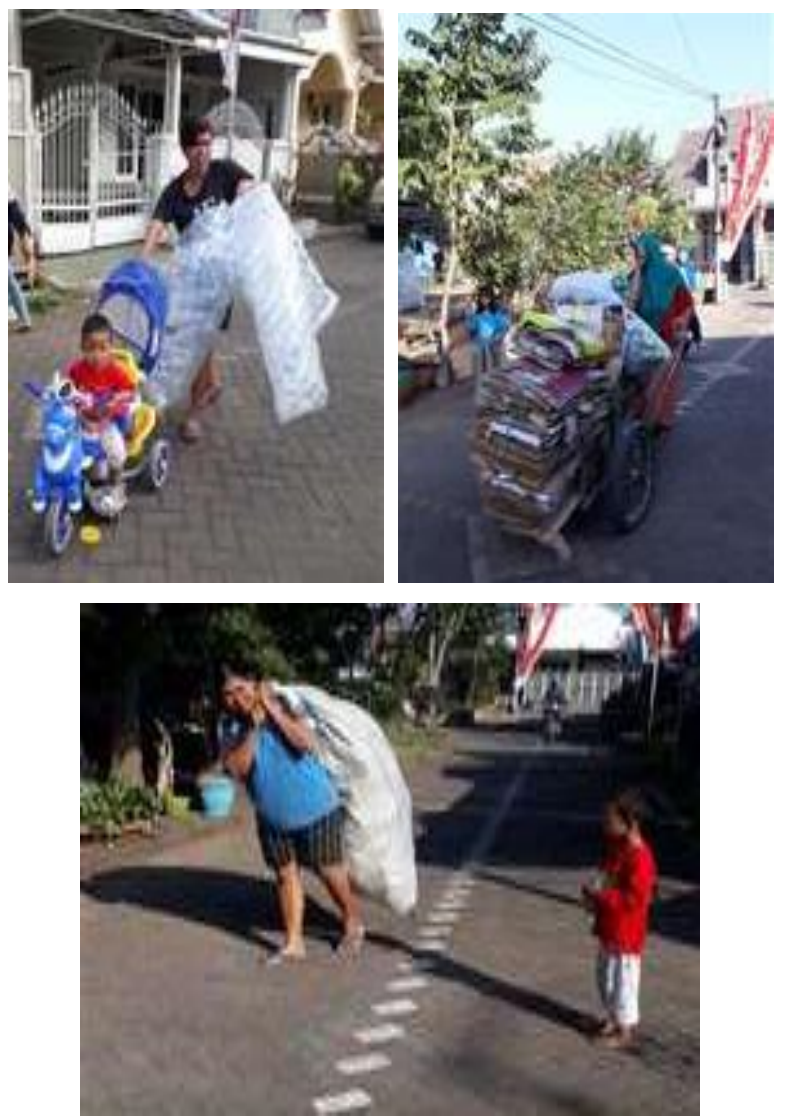

Gambar 8. Kegiatan Pengumpulan Sampah Anorganik oleh Warga (Sumber: Dokumen Pribadi, 2019)

Selanjutnya warga RT 03 membuat pupuk organik cair. Pupuk organik cair dibuat melalui proses komposting. Proses komposting adalah proses dekomposisi secara biologis oleh konsorsium mikroorganisme (Sahwan, 2013). Konsorsium mikroorganisme merupakan kombinasi beberapa mikroorganisme dalam sebuah medium yang memiliki fungsi dalam lingkungan yang saling melengkapi (Sahlan, 2014). Proses pengelolaan sampah organik menjadi pupuk organik cair ini, selain mengatasi masalah sampah yang terjadi di RT 03, juga dapat mengatasi masalah defisiensi bahan organik tanah (Sahwan, 2013). Dengan demikian, diharapkan pemberian pupuk pada tanaman dapat menyuburkan tanaman.

Sebagaimana telah disampaikan sebelumnya, pupuk organik cair dibuat dari bahan sampah organik, dengan menggunakan tong komposter. Tong komposter ini dibeli oleh warga dari perajin tong komposter yang ada di daerah Jl. S. Supriyadi Kel, Sukun, Kec. Sukun. Warga sudah dapat membuat pupuk organik cair sendiri, karena sudah belajar membuatnya ketika kegiatan studi banding. Sampah organik yang digunakan sebagai bahan baku untuk membuat pupuk organik cair adalah kulit buah (kecuali kulit buah yang berkayu, misalnya kulit durian), sisa potongan sayur yang masih mentah, rumput liar, daundaunan kering, dll.

Pembuatan pupuk organik cair dilakukan dengan memasukkan sampah organik ke dalam tong komposter. Sebelum sampah organik tersebut dimasukkan ke dalam komposter, terlebih dahulu dipotong kecil-kecil dengan ukuran $0,5-1 \mathrm{~cm}$. Proses ini dilakukan secara terus menerus ketika ada sampah organik yang dihasilkan warga. Setelah kurang lebih 2 pekan, secara otomatis pupuk cair organik ini akan mengalir melalui selang kecil yang berada di bak penampungan yang terletak di bagian bawah tong komposter. Gambar 9 menujukkan proses menampung pupuk cair organik.

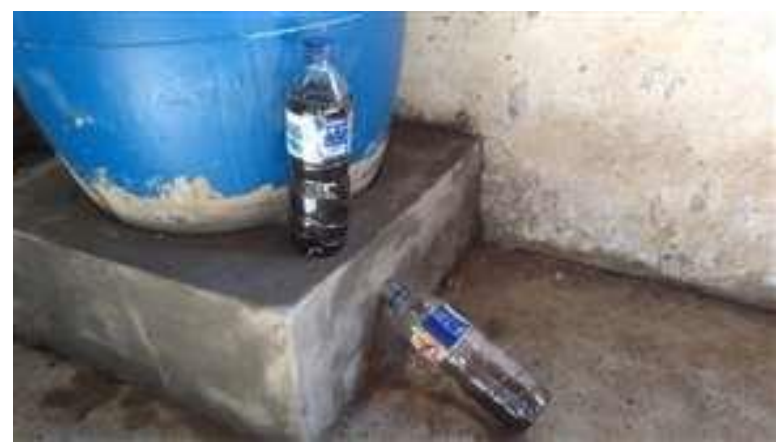

Gambar 9. Proses Menampung Pupuk Cair Organik yang Dihasilkan dari Proses Pengomposan. (Sumber: Dokumen Pribadi, 2019) 
Kegiatan selanjutnya adalah pemilahan sampah anorganik.Kegiatan ini dilakukan satu bulan sekali. Sampah anorganik yang sebelumnya telah dikumpulkan oleh warga di tempat penyimpanan sampah anorganik, kemudian dipilah menjadi dua golongan, yaitu sampah anorganik yang dapat dimanfaatkan dan sampah anorganik yang dijual. Sampah organik yang dijual, selanjutnya dijual kepada pengepul sampah atau disedekahkan kepada pemulung. Uang hasil penjualan sampah, kemudian dimasukkan ke dalam kas RT. Gambar 10 merupakan dokumentasi kegiatan pemilahan sampah anorganik.

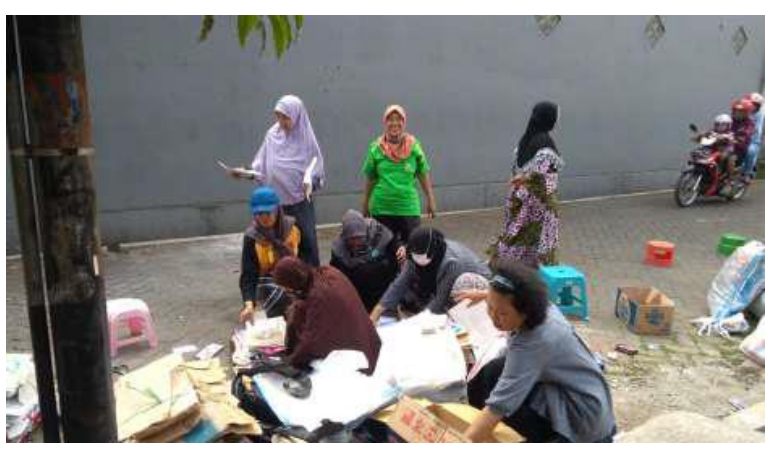

Gambar 10. Proses Pemilahan Sampah Anorganik (Sumber: Dokumen Pribadi, 2019)

Kegiatan lain yang dilakukan oleh dasa wisma Azalea adalah pemanfaatan sampah anorganik. Contoh sampah anorganik yang akan dimanfaatkan antara lain plastik bekas bungkus minyak goreng, kaleng bekas kemasan kue kering atau susu, kemasan bekas makanan instan, plastik bekas kemasan cat, botol plastik bekas kemasan air mineral, kresek bekas, dll. Sampah-sampah tersebut kemudian dimanfaatkan menjadi pot untuk menanam tanaman, brooch, hiasan, asbak tempat puntung rokok yang diletakkan di dekat pintu pagar rumah, dll. Sebagai informasi, berkaitan dengan asbak, benda ini sengaja disediakan di depan masing-masing rumah yang salah satu anggota keluarganya ada yang merokok. Dengan demikian, diharapkan tidak ada anggota keluarga yang merokok ketika berada di dalam rumah. Gambar 11a - 11e merupakan dokumentasi barang-barang yang dihasilkan dari kegiatan pemanfaatan sampah anorganik, sedangkan Gambar 12 merupakan kegiatan pembuatan hiasan dengan memanfaatkan sampah anorganik.
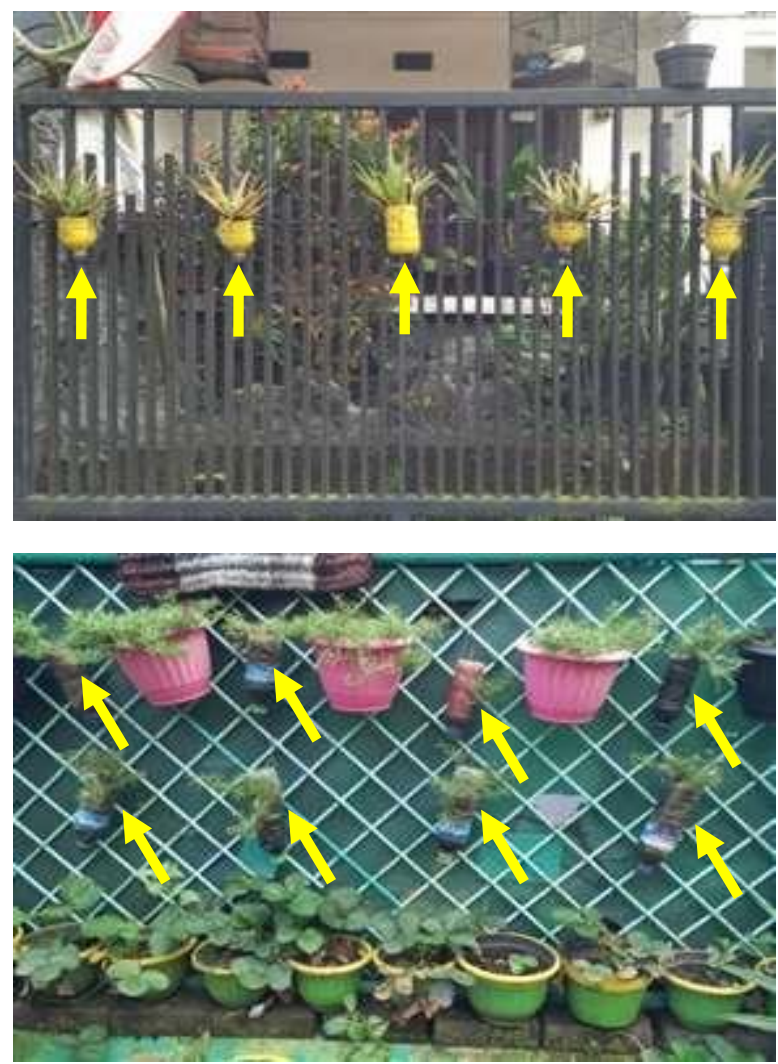

Gambar 11a. Pemanfaatan botol plastik bekas kemasan air mineral sebagai tempat menanam tanaman (Tanda Panah Kuning) (Sumber: Dokumen Pribadi, 2019)

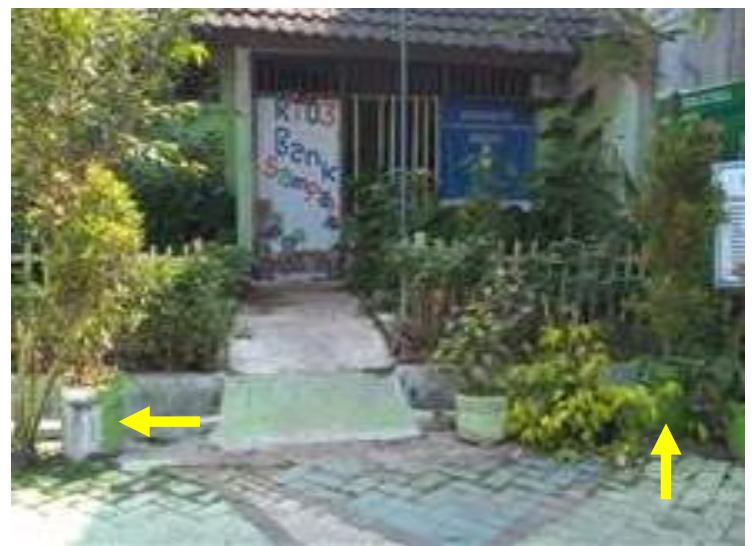

Gambar 11b. Pemanfaatan plastik bekas kemasan cat sebagai tempat menanam tanaman (tanda panah kuning) (Sumber: Dokumen Pribadi, 2019)

Susilo Bektti - Kegiatan Pengelolaan Sampah dan Penghijauan oleh Dasa Wisma Azalea RT 3 RW 16 Desa Mangliawan Kecamatan Pakis Kabupaten Malang 


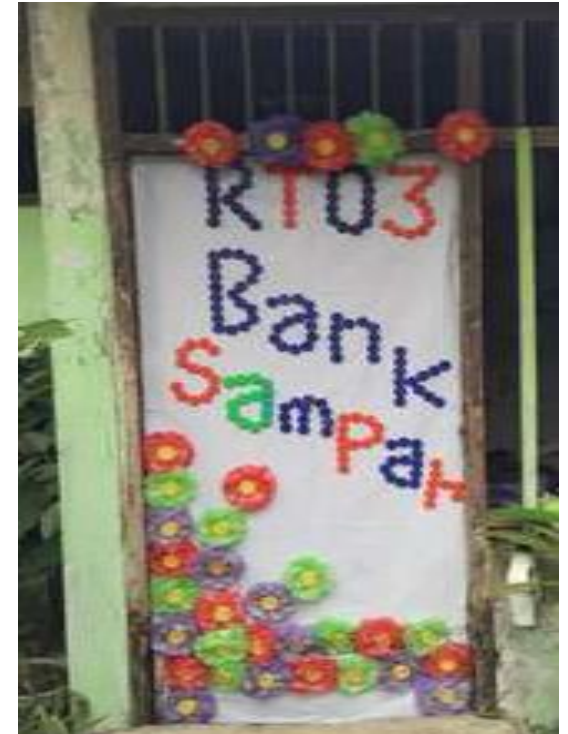

Gambar 11c. Pemanfaatan kresek bekas dan tutup botol plastik sebagai hiasan (Sumber: Dokumen Pribadi, 2019)
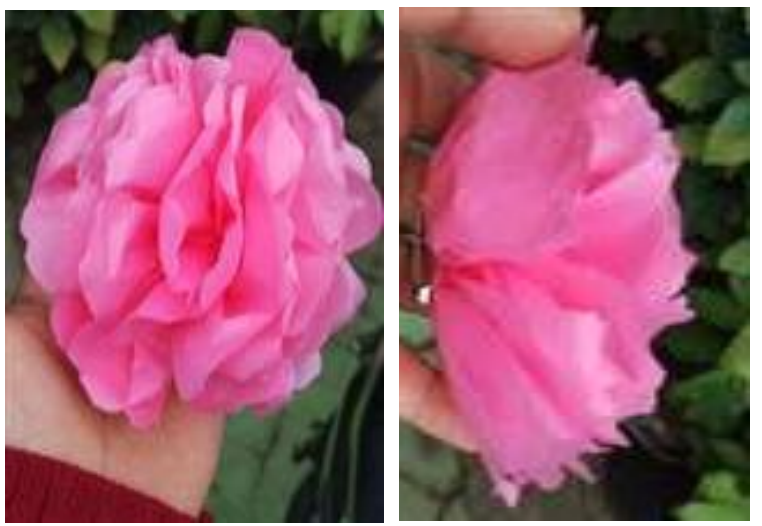

Gambar 11d. Pemanfaatan kresek bekas dan sebagai brooch (Sumber: Dokumen Pribadi, 2019)

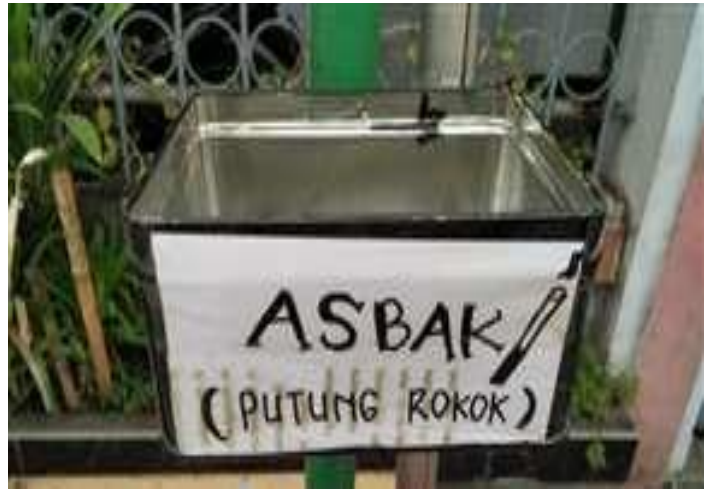

Gambar 11e. Pemanfaatan kaleng bekas kemasan kue kering sebagai asbak (Sumber: Dokumen Pribadi, 2019)

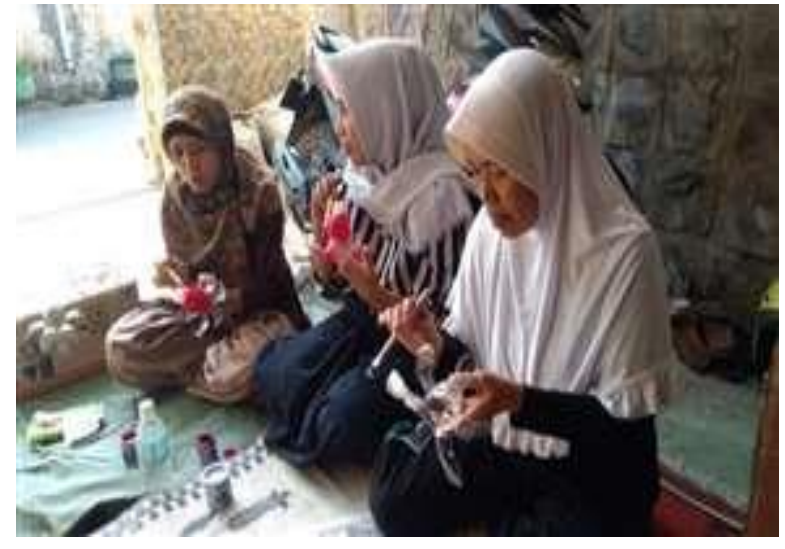

Gambar 12. Kegiatan membuat hiasan dengan sampah anorganik (Sumber: Dokumen Pribadi, 2019)

Dasa Wisma Azalea juga melakukan Penanaman TOGA, sayuran, tanaman yang menghasilkan buah, dan tanaman hias.Kegiatan penanaman dilakukan di taman TOGA, pekarangan rumah warga, maupun di lahan kosong yang ada di lingkungan sekitar RT 03. Sebagaimana yang telah disampaikan sebelumnya, salah satu pemanfaatan sampah anorganik adalah untuk menanam tanaman. Oleh karena itu, selain menggunakan pot plastik dan polybag, kegiatan penanaman dilakukan dengan memanfaatkan sampah anorganik. Dokumentasi kegiatan menanam tersaji pada Gambar 13.

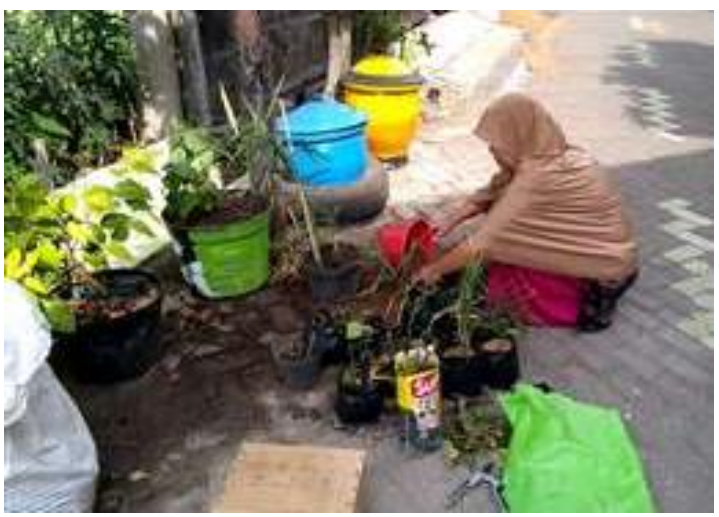

Gambar 13. Kegiatan menanam berbagai jenis tanaman (Sumber: Dokumen Pribadi, 2019)

Jenis TOGA yang ditanam warga antara lain sirih, kunyit, jahe, sereh, beluntas, lidah buaya, dll. Jenis sayuran yang ditanam antara lain sawi, kangkung, selada, tomat, bayam,

Susilo Bektti - Kegiatan Pengelolaan Sampah dan Penghijauan oleh Dasa Wisma Azalea RT 3 RW 16 Desa Mangliawan Kecamatan Pakis Kabupaten Malang 
singkong dll. Jenis tanaman buahnya antara lain mangga, pepaya, dan belimbing. Jenis tanaman hias yang ditanam warga antara lain palem raja, anggrek, alamanda, bunga sepatu, lidah mertua, kaktus dll.

Setelah melakukan penanaman, warga melakukan perawatan tanaman secara berkala. Salah satu kegiatan perawatan tanaman adalah pemupukan. Kegiatan pemupukan dilakukan dengan pupuk cair yang dihasilkan dari proses pengomposan. Kegiatan perawatan lainnya adalah penyiraman, penggemburan tanah, dan pembersihan gulma yang tumbuh di sekitar tanaman. Dokumentasi kegiatan perawatan tanaman sebagaimana tersaji pada Gambar $14 \mathrm{a}$ dan $14 \mathrm{~b}$.

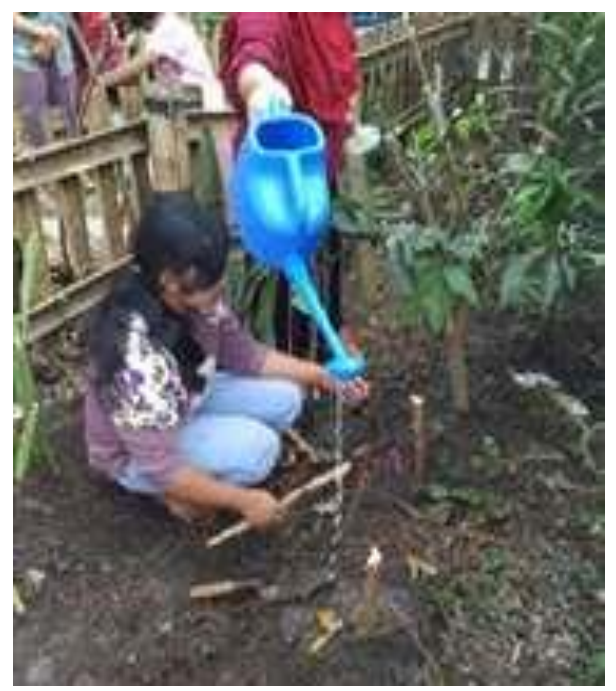

Gambar 14a. Kegiatan menyiram tanaman (Sumber: Dokumen Pribadi, 2019).

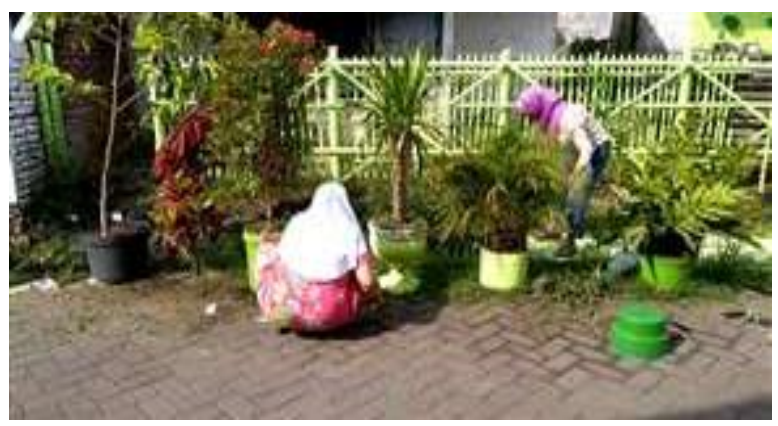

Gambar 14b. Kegiatan pembersihan gulma yang tumbuh di sekitar tanaman (Sumber: Dokumen Pribadi, 2019)
Kegiatan terakhir adalah pemanenan tanaman. Kegiatan ini dilakukan secara bersama-sama melalui kegiatan kerja bakti. Hasil panen akan dimanfaatkan secara bersama-sama oleh warga RT. Gambar 15 merupakan dokumentasi kegiatan panen, sedangkan Gambar 16 merupakan dokumentasi hasil panen.
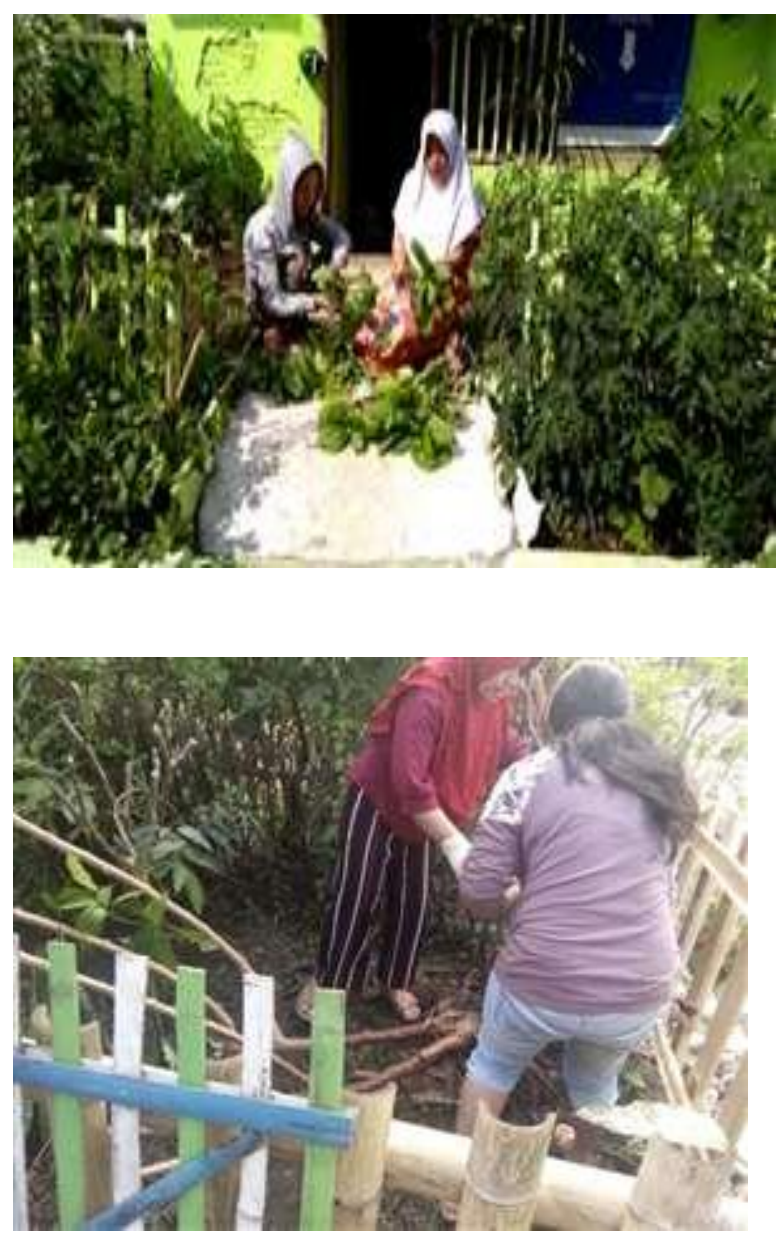

Gambar 15. Kegiatan panen sayuran dan singkong (Sumber: Dokumen Pribadi, 2019)

Susilo Bekți - Kegiatan Pengelolaan Sampah dan Penghijauan oleh Dasa Wisma Azalea RT 3 RW 16 Desa Mangliawan Kecamatan Pakis Kabupaten Malang 

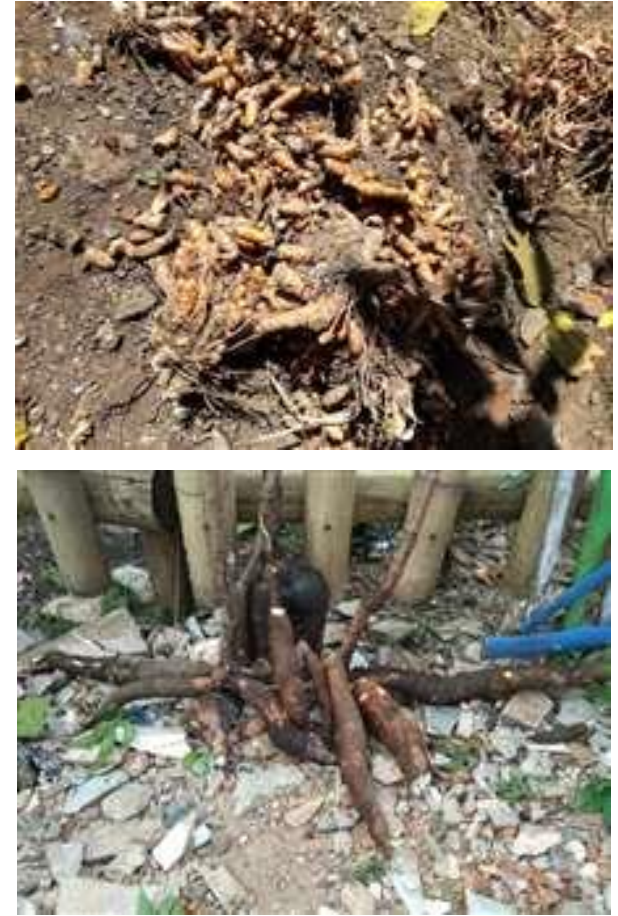

Gambar 16. Hasil Panen (Sumber: Dokumen Pribadi, 2019)

Demikianlah serangkaian kegiatan yang dilakukan oleh Dasa Wisma Azalea. Melalui kegiatan ini diharapkan dapat mewujudkan lingkungan RT 3 yang bersih dan hijau. Selain itu, diharapkan pula warga RT 3 RW 16 Desa Mangliawan Kecamatan Pakis dapat mengurangi jumlah sumbangan sampah ke TPA di Kabupaten Malang, sehingga ke depannya diharapkan dapat mengurangi jumlah timbulan sampah yang dihasilkan oleh warga Kabupaten Malang.

\section{KESIMPULAN}

Rangkaian program yang telah dilakukan oleh Dasa Wisma Azalea telah dapat mewujudkan lingkungan RT 03 yang bersih dan hijau. Hal ini dibuktikan dari diraihnya juara ke III pada lomba kebersihan tahun 2018.

\section{UCAPAN TERIMA KASIH}

Ucapan terima kasih disampaikan kepada beberapa pihak berikut ini.
1. Direktorat Riset dan Pengabdian Masyarakat (DRPM) Kemenristekdikti, yang telah memberikan dana untuk mendukungpelaksanaan kegiatan ini.

2. IKIP Budi Utomo Malang, Ketua RT 03, Dasa Wisma Azalea, dan Warga RT 03 yang telah mendukung penuh pelaksanaan program ini.

\section{DAFTAR PUSTAKA}

Darmawan, Awan. 2014. Perilaku Masyarakat dalam Mengelola Sampah di Kota Bima Nusa tenggara Barat. Jurnal Pembangunan Wilayah \& Kota 2014; 10(2)

Erwin, Mohammad. 2019. Dinas Lingkungan Hidup Kabupaten Malang Sebut Sudah Melakukan Pengelolaan Sampah Setiap Hari. Surya Malang.com. Minggu, 24 Februari 2019.

https://suryamalang.tribunnews.com/20 19/02/24/dinas-lingkungan-hidupkabupaten-malang-sebut-sudahmelakukan-pengelolaan-sampah-setiaphari

Peraturan Menteri Dalam Negeri Nomor 33

Tahun 2010 tentang Pedoman

Pengelolaan Sampah

Peraturan Daerah Kabupaten Malang Nomor

12 tahun 2012 tentang Pengelolaan

Sampah

Ramon, Agus. \& Afriyanto. 2015.

Karakteristik Penanganan Sampah

Rumah Tangga di Kota Bengkulu.

Jurnal Kesehatan Masyarakat Andalas 2015; 10(1) e-ISSN: 2442-6725

Sahlan, A. Q., Kusdiyantini, E., Pujiyanto, S., Antonius, S. 2014. Isolasi dan

Karakterisasi Isolat Konsorsium Bakteri Lahan Pertanian sebagai Potensi Degradasi Pestisida Propoxur. Jurnal Biologi 2014; 3(3)

Sahwan, Firman L. 2013. Potensi

Komposting Sampah Skala Rumah 
Tangga untuk Mereduksi Timbulan

Sampah (Pilot Proyek di Perumahan

Puspiptek Serpong). Jurnal Tek. Ling.

2013; 14(1)

Sudiro, Setyawan, Arief., Nulhakim,

Lukman. 2018. Model Pengelolaan

Sampah Permukiman di Kelurahan

Tunjung Sekar Kota Malang. Plano

Madani 2019; 7(1)e-ISSN: 2541-2973

Usman, Said. 2016. Strategi Pengelolaan

Sampah Rumah Tangga di Kota

Tarakan Kalimantan Utara. Jurnal

Ekonomi Pembangunan 2016; 5(3)

Susilo Bektti - Kegiatan Pengelolaan Sampah dan Penghijauan oleh Dasa Wisma Azalea RT 3 RW 16 Desa Mangliawan Kecamatan Pakis Kabupaten Malang 